\title{
PENGARUH ACTIVITY DAILY LIVINGTRAINING TERHADAP KEMANDIRIAN PASIEN KANKER PAYUDARA DI MURNI TEGUH MEMORIAL HOSPITAL
}

\author{
Ongku Bosar Hasibuan \\ Dosen Prodi Ilmu Keperawatan, STIKes Murni Teguh, Jalan Jawa No 2 Gang Buntu Medan
}

E-mail: hasbers.bayo@yahoo.com

\begin{abstract}
ABSTRAK
Kanker payudara merupakan jenis kanker yang sering dialami oleh wanita setelah kanker kulit, dimulai dari saluran atau lobus dan menetap pada payudara dan dapat menyebar pada bagian tubuh lain. Salah satu terapi yang dapat dilakukana adalah kemoterapi yang dilakukan untuk membunuh sel kanker dengan menggunakan obat anti kanker (sitotastika). Salah satu efek samping kemoterapi adalah perubahan fisik, kognitif (mental) dan gangguan kesejahteraan emosional, penurunan kekuatan otot, sensai, energi, rasa sakit yang berdampak terhadap kemapuan pasien untuk melakukan Activity Daily Living's (ADL's). Salah satu intervensi untuk mengatasi gangguan pemenuhan kebutuhan Activity Daily Living's responden adalah Activity Daily Living's Training. Tujuan penelitian ini untuk mengidentifikasi pengaruh Activity Dailiy Living's Training terhadap kemandirian pasien kanker payudara di Murni Teguh Memorial Hospital. Jenis penelitian ini quasi eksperimen dengan design nonequivalent pre-posttest. Sampel penelitian ini adalah pasien kanker payudara yang menjalani kemoterapi serta mengalami gangguan kemampuan Activity Daily Living's dengan tekhnik accidental sampling sebanyak 35 orang. Kemandirian Activity Daily Living's sebelum dan sesudah Activity Daily Living's Training dianalisa dengan uji wilcoxon test dengan nilai $p<0.05$. Penelitian ini menunjukkan peningkatan kemampuan responden melakukan Activity Daily Living's di rumah. Program latihan ini dapat menjadi masukan kepada perawat untuk memberikan program ini melalui home care.
\end{abstract}

Kata kunci: Activity Daily Living Training, kemandirian pasien kanker payudara

\section{ABSTRACT}

Breast cancer is a once of cancer desease is often experienced to women after skin cancer, Thi is kind starting from the canal lobe and setting to breast and can spread to other parts of body. One of the therapies is chemoterapy whic's done to kill cancer cells using by anti-cancer drugs (cytotastica). One of the effects chemoterapy is physical, cognitive (mental) chnages and emotional weel-being, decreased of muscule sterngth, sensation, energy, pain whic can make affet to their ability to Activity Daily Living's (ADL's). One of the intervenstion to overcome the disruption of ADL's is Program Activity Daily Living's Training. The Purpose of this reserach was to identify the effect of Activity Daily Living's Training to independence of ADL's breas cancer patient's at Murni Teguh Memorial Hospital. This research is quasi-experimental with pre-posstes design. The sample is breast cancer patient's who underwent chemotherapy and experienced the distruption theri ADL's ability with accidental sampling technique with 35 respondent. The ability for independece respondent to make a ADL's before an after Actctivity Daily Living's Training was anlyzed by wilcoxon test with $p$ value $<0,05$. This study shows have a increased ability to make ADL's respondent at home. This training program can be inout to nurses to provide this program through home care.

Keywords: Activity Daily Living's Training, independence breast cancer

\section{PENDAHULUAN}

Kanker merupakan penyakit yang ditandai dengan pertumbuhan dan penyebaran sel abnormal yang disebabkan oleh berbagai faktor seperti penggunaan tembakau, genetik, hormon dan gangguan kekebalan tubuh serta dapat mengakibatkan kematian. Kanker payudara merupakan jenis kanker yang sering dialami oleh wanita setelah kanker kulit, dimulai dari saluran atau lobus dan menetap pada payudara dan dapat menyebar pada bagian tubuh lain. Terapi pasin kanker payudara dapat dilakukan 
dengan cara pembedahan, kemoterapi, radiasi atau terapi hormonal yang menyebabkan efek samping seperti perubahan fisik, kognitif (mental) dan gangguan kesejahteraan emosional, penurunan kekuatan otot, sensai, energi, rasa sakit yang berdampak terhadap kemapuan pasien untuk melakukan Activity Daily Living's (ADL's) seperti berpakaian dan menyiapkan makanan (American Occupational Therapy, 2011; American Cancer Society, 2014).

Menurut data GLOBOCAN (2012) terdapat 14,1 juta kasus kanker baru dan 8,2 juta diantaranya mengalami kematian. Pada tahun 2012 terjadi peningkatan penderita kanker payudara sebanyak 1.7 juta kasus dengan jumlah kematian sebanyak 522.000 kematian. Pasien kanker sering mengalami keluhan fisik seperti kelemahan akibat kurangnya energi didalam tubuh sehingga mengakibatkan istirahat yang cukup lama mengakibatkan hilangnya fungsi tubuh, kelemahan dan kehilangan gerak otot sehingga mengalami gangguan terhadap kemampuan melakukan Actiivity Daily Living's (American Cancer Society, 2014 ; International Agency for Research on Cancer (IARC), 2012).

Menurut Persatuan Ahli Bedah Onkologi (2005) salah satu pengobatan pasin kanker payudara adalah dengan kemoterapi yang dilakukan untuk membunuh sel kanker dengan menggunakan obat anti kanker (sitotastika). Kemoterapi dapat mengakibatka n efek samping yaitu rambut rontok, gangguan pada sum-sum tulang, berkurangnya hemoglobin, berkurangnya trombosit, berkurangnya sel darah putih, lemah, merasa lelah, sesak nafas, mudah mengalami perdarahan, mudah terinfeksi, kulit membiru/menghitam, kering, gatal pada mulut, gatal pada tenggorokan, sariawan, sulit menelan, mual muntah, nyeri perut dan penurunan nafsuk seks dan kesuburan akibat penurunan produksi hormon (Bahktiar, 2012).

Berdasarkan penelitian Fangel, L.M.V., Panobianco, M.S., Kebbe, L.M., Almeida, A.M. \& Gozzo, T.O (2013) bahwa wanita yang mengalami kanker payudara memiliki keterbatasan untuk melakukan perawatan diri sehari-hariseperti pekerjaan rumah tangga, perawatan diri dan kegiatan lainnya yang berdampak terhadap penurunan kualitas hidup mereka.

Menurut Lubis (2009) dampak dari kemoterapi dapat menyebabkan ketidakmamp uan melakukan aktivitas sehari-hari yang mengakibatkan terjadinya ketergantungan kepada orang lain untuk memenuhi perawatan diri sehari-hari. Berdasarkan penelitian Zhao, Li, Jun dan Balluz (2013) menyatakan bahwa perbandingan kemampua $\mathrm{n}$ berjalan cepat, bersepeda, berkebun, berlari, aerobik, pekerjaan halaman yang nmengakibatkan peningkatan beban kerja jantung dan pernapasan antara pasien kanker dan yang tidak mengalami penyakit kanker adalah 1) rata-rata < 150 menit/minggu yaitu $26,7 \%$ pasien kanker dan $23 \%$ yang pasien yang tidak mengalami penyakit kanker dan 2) rata-rata $>150$ menit/minggu yaitu 56,1\% pasien kanker dan $65,7 \%$ yang tidak mengalami penyakit kanker.

Keterbatasan perawatan diri dan kemampuan Activiy Daily Livng's (ADL's) pasien kronis seperti pasien kanker sudah menjadi perhatian dunia. Hal ini terjadi akibat kurangnya penyampaian informasi kepada pasien dan keluarga tentang perawatan diri sehari-hari akibat penyakit dan terapi yang dijalaninya (Taylor \& Renpenning, 2011). Salah satu intervensi yang dapat diberikan oleh petugas kesehatan untuk meningkatkan pelaksanaan Activity Daily Living's pasien kanker yaitu dengan memberikan program latihan Activity Daily Living Training yang diyakini mampu meningkatkan kemandirian pasien untuk menjalankan fungsi kehidupannya seperti perawatan diri sehariharinya (Nasir \& Muhith, 2010).

Pasein kanker yang menjalani perawatan harus aktif melakukan latihan pergerakan untuk menajga dan dapat menjalankan kemampuan perawatan diri sehari-hariseusai dengan kemampuan tubuh terhadap aktifitas fisik tersebut. Latihan pergerakan harus dilakukan sesuai dengan anjuran petugas kesehatan dan terprogram selama masa pengobatan atau perawatan. Periksakan kondisi kesehatan anda sebelum melakukan latihan pergerakan serta dapat mengkonsultasikan kepada ahli terapi fisik untuk membantu latihan pergerakan yang 
aman, efektif dan menyenangkan bagi anda (American Cancer Society, 2014).

Berdasarkan wawancara yang dilakukan oleh peneliti pada bulan Juni 2018 di Murni Teguh Memorial Hospital terhadap beberapa pasien kanker payudara yang menjalani kemoterapi memiliki keterbatasan melakukan Activity Daily Living's (ADL's) di rumah dengan alasan kelemahan yang dirasakan sehingga ketakutan akan melakukan aktivitas. Hasil wawancara juga menunjukkan perawat telah menyampaiakn informasi terkait dengan perawatan diri pasien di rumah.

Berdasarkan uraian tersebut, maka peneliti tertarik untuk meneliti pengaruh Activity Daily Living's Training terhadap tingkat kemandirian pasien kanker di Murni Teguh Memorial Hospital.

\section{METODE}

Penelitian ini merupakan penelitian kuantitatif dengan jenis quasi-eksperimental yaitu metode penelitian yang digunakan untuk menguji hubungan sebab akibat atau mencari pengaruh dari suatu intervensi terhadap populasi tanpa adanya randomisasi penentuan subjek penelitian.Rancangan penelitian yang digunakan adalah nonequivalentcont pre-post test without control group design yang dilakukan dengan memberikan perlakuan pada kedua atau lebih kelompok group bertujuan untuk membandingkan hasil intervensi sebelum dan sesudah diberikan (Wood \& Heber, 2014).Penelitian ini hanya menggunakan kelompok intervensi tanpa mengggunakan kelompok kontrol sebagai pembanding.

Penelitian ini dilakukan di Murni Teguh Memorial Hospital dengan alasan Rumah Sakit ini adalah salah satu Rumah Sakit tipe $\mathrm{B}$ dengan akreditasi Paripurna yang memiliki keunggulan di bidang onkologi atau kanker. Adapun waktu penelitian ini adalah dilaksanakan bulan Juli sampai dengan Agustus 2018.

Populasi merupakan seluruh subjek yang memiliki karakteristik atau kriteria yang akan diteliti, dapat berupa orang, benda, catatan medis pasien, diagnosis pasien, lama perawatan pasien dan lain-lain (Fain, 2009). Populasi dalam penelitian ini adalah seluruh pasien kanker payudarayang datang berobat ke Murni Teguh Memorial Hospital Medan. Sampling dalam penelitian ini adalah convenience (accidental) sampling, yaitu pemilihan sampel tanpa disengaja bertemu dengan responden serta memiliki kriteria sesuai dengan penelitian atau berdasarkan kebetulan saja, yaitu siapa saja responden yang bertemu dengan peneliti serta sesuai dengan kriteria sampel yang ditetapkan dan bersedia menjadi responden, maka responden tersebut dijadikan sampel penelitian (Fain, 2009). Adapun besarnya sampel penelitian ini adalah 35 orang.

Apadun kriteria pengambilan sampel yang diinginkan (inklusi) adalah sebagai berikut pasien kanker payudara yang mengikuti kemoterapi, bersedia menjadi responden, bisa membaca dan menulis, kooperatif dan responden yang tidak memiliki komplikasi penyakit seperti luka akibat kanker, sesak napas, mengalami gangguan kemampuan melakukan perawatan diri sehari-hari atau ketergantungan untuk melakukan perawatan diri sehari-hari di rumah.

Strategi pengumpulan data penelitian ini mulai dari pengurusan izin tempat penenlitian dengan mengajukan surat permohonan penelitian dari pimpinan STIKes Murni Teguh yang ditujukan ke bagian pendidikan dan penelitian Murni Teguh Memorial Hospital. Setelah mendapat surat persetujuan dari bidang Diklit Murni Teguh Memorial Hospital, surat pengantar izin penelitian diberikan ke ruangan kemotera pi. Kemudian melakukan penelitian. Sebelum melakukan penelitian, peneliti memberikan penjelasan tentang penelitian yang akan dilakukan. Peneliti menjelaskan maksud dan tujuan serta manfaat penelitian, kemudian meminta persetujuan (informed consent).Setelah responden bersedia menjadi responden penelitian, maka kegiatan pretest dilakukan.Sebelum memberikan intervensi, peneliti melakukan penialaian kemampuan melakukan perawatan diri sehari-hari responden dengan menggunakan kuesioner kemampuan perawatan diri sehari-hari. Pengumpulan data dilakukan dengan cara metode wawancara yang sesuai dengan kuesioner. Pelaksanaan intervensi ini dilaksanakan pada kelompok intervensi 
sebanyak 35 responden selama menjalani terapi kemoterapi. Responden dan keluarga diberikan booklet Activity Daily Living's Training dan menjelaskan tujuan dan penggunaan booklet tersebut. Pada penjelasan ini diharapkan keluarga mampu memahami untuk dapat dijadikan sebagai tim kerjasama pemantau dan pendukung responden untuk melakukan program Activity Daily Living's tersebut di rumah. Program booklet Activity Daily Living's Training dilakukan selama satu bulan dengan program 3 kali latihan dalam seminggu dengan durasi waktu 30 menit setiap latihan.

Peneliti mengumpulkan booklet yang sudah dibagikan sebelumnya, kemudian menilai kembali dengan menggunakan kuesioner tingkat kemampuan responden melakukan perawatan diri sehari-hari responden setelah program latihan selesai diberikan.

Penelitian ini terdiri dari dua variabel. Pertama, variabel Activity Daily Living's Training, yaitu intervensi yang diberikan kepada responden melalui latihan aktivitas sehari-hari yang dilakukan selama 30 setiap latihan menit dalam waktu satu bulan dan sesuai kemampuan responden. Kedua, variabel kemandirian responden melakukan Activity Daily Living's (ADL's) terhadap pemenuhan nutrisi dan cairan, mobilisasi/per gerakan, aktivitas rumah, toileting, bathing, kebersihan diri dan pengobatan yang diukur dengan menggunakan lembar observasi melaui log-book kemampuan $A D L$ 's di rumah dengan indikator ukur mandiri total, membuthkan peralatan atau alat bantu, membutuhkan orang lain sebagai pengawasan atau pemotivasi, membutuhkan pertolongan orang lain dan alat bantu dan ketergantungan total.
Analisa data dilakukan dengan analisa univariat yaitu untuk mengetahui distribusi frekuensi dan persentasi karakteristik responden seperti umur, pendidikan, status ekonomi dan status pernikahan. Data juga dianalisa dengan uji wilcoxon signed rank test yaitu untuk mengidentifikasi perbedaan kemandirian melakukan Activity Daily Living's ( $A D L$ 's).

\section{HASIL DAN PEMBAHASAN}

Berdasarkan hasil uji statistik univariatterhadap tingkat kemandirian responden dalam melakukan Activitiy Daily Living's (ADL's) sebelum intervensi Activity Daily Living's Training dapat dilihat pada tabel 1 bahwa dari 35 responden mayoritas responden membutuhkan pertolongan orang lain dan alat bantu dalam pemenuhan kebutuhan nutrisi dan cairan sebanyak 17 orang $(48,60 \%)$, membutuhkan orang lain sebagai pengawasan atau pemotivasi dalam pemenuhan kebutuhan mobilisasi/pergerakan sebanyak 16 orang $(45,70 \%)$, membutuhkan orang lain sebagai pengawasan atau pemotivasi dalam pemenuhan kebutuhan aktivitas rumah sebanyak 17 orang $(48,60 \%)$, membutuhkan orang lain sebagai pengawasan atau pemotivasi dalam pemenuh an kebutuhan aktivitas toiletingsebanyak 17 orang $(48,60 \%)$, membutuhkan orang lain sebagai pengawasan atau pemotivasi dalam pemenuhan kebutuhan aktivitas bathing sebanyak 17 orang $(48,60 \%)$, membutuhkan orang lain sebagai pengawasan atau pemotivasi dalam pemenuhan kebutuhan aktivitas kebersihan diri sebanyak 18 orang $(51,40 \%)$ dan membutuhkan orang lain sebagai pengawasan atau pemotivasi sebanyak 18 orang $(51,40 \%)$.

Tabel 1. Deskripsi Kemandirian Responden Melakukan Activity Daily Living's Sebelum Intervensi.

\begin{tabular}{cllcc}
\hline \multirow{2}{*}{ No } & \multicolumn{1}{c}{ Tingkat Kemandirian $\boldsymbol{A D L}$ 's } & \multicolumn{2}{c}{ Responden } \\
\cline { 3 - 4 } & & F & \% \\
\hline \multirow{2}{*}{1} & Pemenuhan kebutuhan nutrisi dan cairan & 5 & 14,30 \\
\cline { 2 - 4 } & Membutuhkan peralatan atau alat bantu & 13 & 37,10 \\
\cline { 2 - 4 } & Membutuhkan orang lain sebagai pengawasan atau pemotivasi & 17 & 48,60 \\
\cline { 2 - 4 } & Membutuhkan pertolongan orang lain dan alat bantu & & \\
\hline \multirow{2}{*}{2} & Pemenuhan kebutuhan mobilisasi/pergerakan & 6 & 17,10 \\
\cline { 2 - 4 } & Membutuhkan peralatan atau alat bantu & & \\
\hline
\end{tabular}




\begin{tabular}{|c|c|c|c|}
\hline & Membutuhkan orang lain sebagai pengawasan atau pemotivasi & 13 & 37,10 \\
\hline & Membutuhkan pertolongan orang lain dan alat bantu & 16 & 45,70 \\
\hline \multirow{4}{*}{3} & Pemenuhan kebutuhan aktivitas rumah & & \\
\hline & Membutuhkan orang lain sebagai pengawasan atau pemotivasi & 7 & 20,00 \\
\hline & Membutuhkan pertolongan orang lain dan alat bantu & 11 & 31,40 \\
\hline & Ketergantungan total & 17 & 48,60 \\
\hline \multirow{4}{*}{4} & Pemenuhan kebutuhan aktivitas toileting & & \\
\hline & Membutuhkan peralatan atau alat bantu & 9 & 25,70 \\
\hline & Membutuhkan orang lain sebagai pengawasan atau pemotivasi & 17 & 48,60 \\
\hline & Membutuhkan pertolongan orang lain dan alat bantu & 9 & 25,70 \\
\hline \multirow{4}{*}{5} & Pemenuhan kebutuhan aktivitas bathing & & \\
\hline & Membutuhkan peralatan atau alat bantu & 9 & 25,70 \\
\hline & Membutuhkan orang lain sebagai pengawasan atau pemotivasi & 17 & 48,60 \\
\hline & Membutuhkan pertolongan orang lain dan alat bantu & 9 & 25,70 \\
\hline \multirow{4}{*}{6} & Pemenuhan kebutuhan aktivitas kebersihan diri & & \\
\hline & Membutuhkan peralatan atau alat bantu & 13 & 37,10 \\
\hline & Membutuhkan orang lain sebagai pengawasan atau pemotivasi & 18 & 51,40 \\
\hline & Membutuhkan pertolongan orang lain dan alat bantu & 4 & 11,40 \\
\hline \multirow{3}{*}{7} & Pemenuhan kebutuhan terhadap aktivitas pengobatan & & \\
\hline & Membutuhkan peralatan atau alat bantu & 19 & 54,30 \\
\hline & Membutuhkan orang lain sebagai pengawasan atau pemotivasi & 16 & 45,70 \\
\hline
\end{tabular}

Berdasarkan hasil uji statistic univariatte rhadap tingkat kemandirian responden dalam melakukan Activitiy Daily Living's (ADL's) sesudah intervensi Activity Daily Living's Training dapat dilihat pada tabel 2 bahwa dari 35 responden mayoritas responden membutuhkan peralatan atau alat bantu dan pertolongan orang lain dan alat bantu dalam pemenuhan kebutuhan nutrisi dan cairan sebanyak 15 orang $(42,90 \%)$, membutuhkan orang lain sebagai pengawasan atau pemotivasi dalam pemenuhan kebutuhan mobilisasi/pergerakan sebanyak 20 orang $(57,10 \%)$, membutuhkan orang lain sebagai pengawasan atau pemotivasi dalam pemenuh an kebutuhan aktivitas rumah sebanyak 14 orang $(40,00)$, membutuhkan peralatan atau alat bantu dan membutuhkan orang lain sebagai pengawasan atau pemotivasi dalam pemenuhan kebutuhan aktivitas toiletingseba nyak 17 orang $(48,60 \%)$, membutuhkan orang lain sebagai pengawasan atau pemotivasi dalam pemenuhan kebutuhan aktivitas bathing sebanyak 15 orang $(42,90 \%)$, membutuhkan peralatan atau alat bantu dalam pemenuhan kebutuhan aktivitas kebersihan diri sebanyak 21 orang $(60,00 \%)$ dan membutuhkan orang lain sebagai pengawasan atau pemotivasi sebanyak 17 orang $(48,60 \%)$.

Tabel 2. Deskripsi Kemandirian Responden Melakukan Activity Daily Living's Sesudah Intervensi.

\begin{tabular}{|c|c|c|c|}
\hline \multirow{2}{*}{ No } & \multirow{2}{*}{ Tingkat Kemandirian $A D L$ 's } & \multicolumn{2}{|c|}{ Responden } \\
\hline & & $\mathbf{F}$ & $\%$ \\
\hline \multirow{5}{*}{1} & Pemenuhan kebutuhan nutrisi dan cairan & & \\
\hline & Mandiri total & 3 & 8,60 \\
\hline & Membutuhkan peralatan atau alat bantu & 15 & 42,90 \\
\hline & Membutuhkan orang lain sebagai pengawasan atau pemotivasi & 15 & 42,90 \\
\hline & Membutuhkan pertolongan orang lain dan alat bantu & 2 & 5,70 \\
\hline \multirow{4}{*}{2} & Pemenuhan kebutuhan mobilisasi/pergerakan & & \\
\hline & Membutuhkan peralatan atau alat bantu & 14 & 40,00 \\
\hline & Membutuhkan orang lain sebagai pengawasan atau pemotivasi & 20 & 57,10 \\
\hline & Membutuhkan pertolongan orang lain dan alat bantu & 1 & 2,90 \\
\hline \multirow{3}{*}{3} & Pemenuhan kebutuhan aktivitas rumah & & \\
\hline & Membutuhkan peralatan atau alat bantu & 2 & 5,70 \\
\hline & Membutuhkan orang lain sebagai pengawasan atau pemotivasi & 14 & 40,00 \\
\hline
\end{tabular}




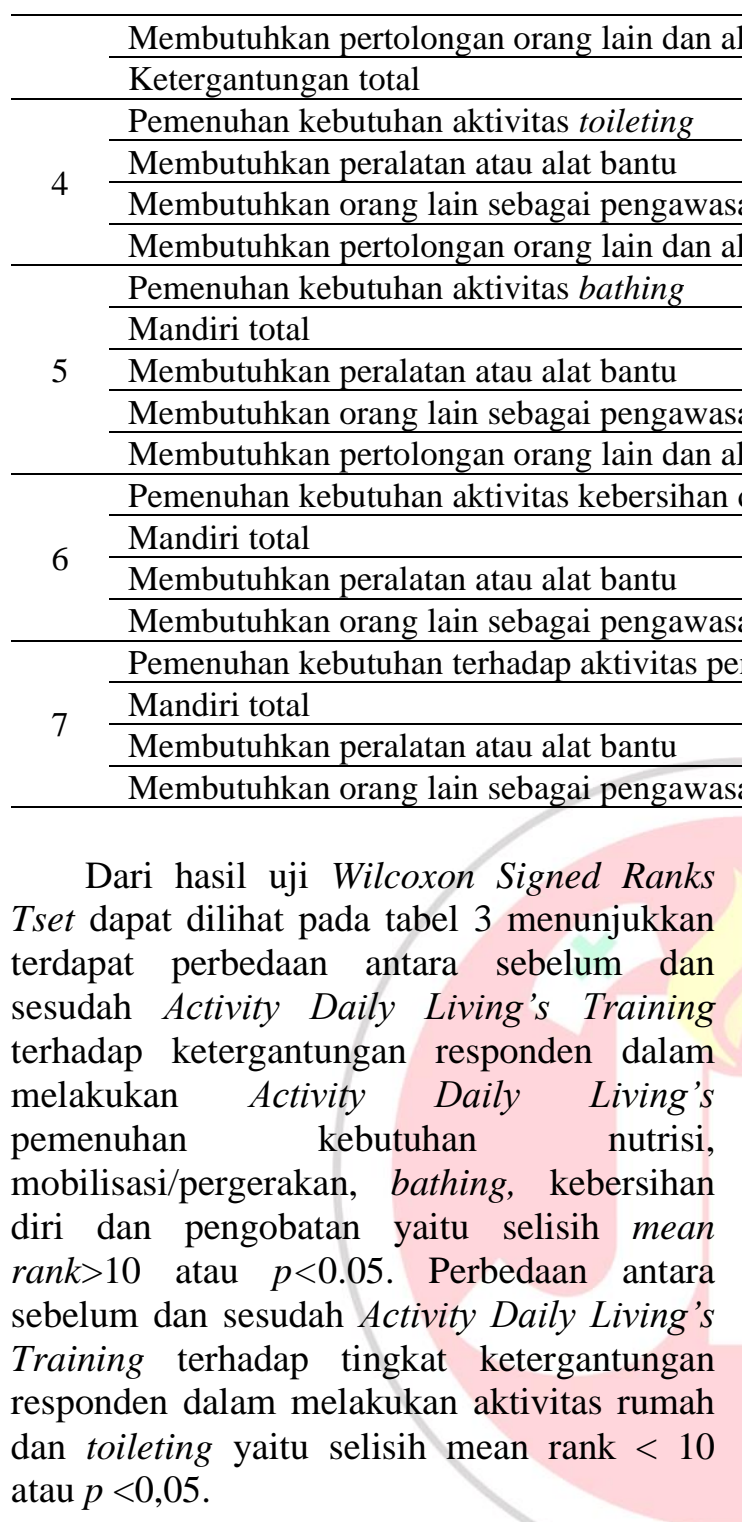

Tabel 3. Perbedaan Activity Daily Living's Sebelum dan Sesudah Intervensi.

\begin{tabular}{|c|c|c|c|c|}
\hline \multirow[b]{2}{*}{$\begin{array}{l}\mathbf{N} \\
\mathbf{0}\end{array}$} & \multirow{2}{*}{$\begin{array}{c}\text { Activity Daily } \\
\text { Living's } \\
\text { (ADL's) } \\
\end{array}$} & \multicolumn{2}{|c|}{ Mean Rank } & \multirow[b]{2}{*}{$\begin{array}{c}\text { Nilai } \\
P\end{array}$} \\
\hline & & $\begin{array}{c}\text { Sebel } \\
\text { um }\end{array}$ & $\begin{array}{l}\text { Sesu } \\
\text { dah }\end{array}$ & \\
\hline 1 & $\begin{array}{l}\text { Aktivitas } \\
\text { pemenuhan } \\
\text { kebutuhan } \\
\text { nutrisi dan } \\
\text { cairan }\end{array}$ & 0,00 & 13,50 & 0,000 \\
\hline 2 & $\begin{array}{l}\text { Aktivitas } \\
\text { mobilisasi/per } \\
\text { gerakan }\end{array}$ & 0,00 & 10,50 & 0,000 \\
\hline 3 & $\begin{array}{l}\text { Aktivitas } \\
\text { rumah }\end{array}$ & 0,00 & 8,00 & 0,000 \\
\hline 4 & $\begin{array}{l}\text { Aktivitas } \\
\text { toileting }\end{array}$ & 0,00 & 8,57 & 0,001 \\
\hline 5 & Aktivitas & 0,00 & 11,50 & 0,000 \\
\hline
\end{tabular}

\begin{tabular}{lllll}
\hline bathing & & & \\
\hline 6 & $\begin{array}{l}\text { Aktivitas } \\
\text { kebersihan diri }\end{array}$ & 0,00 & 13,00 & 0,000 \\
\hline 7 & $\begin{array}{l}\text { Aktivitas } \\
\text { pengobatan }\end{array}$ & 0,00 & 11,00 & 0,000 \\
\hline
\end{tabular}

Penelitian ini menunjukkan terjadi perubahan kemampuan Activity Daily Living's sebelum Activity Daily Living's Training. Hal ini dikarenakan kurangnya energi dalam tubuh akibat terjadinya proses pertumbuhan sel kanker dan terjadinya kelemahan akibat efek samping kemoterapi yang mengakibatkan responden membatasi diri untuk melakukan kegiatan Activity Daily Living's. Penelitian ini sejalan dengan pernyataan Ahli Bedah Onkologi (2005) bahwa pasien kanker payudara yang menjalani kemoterapi dapat mengakibatkan efek samping rambut rontok, gangguan pada sum-sum tulang, berkurangnya hemoglobin, berkurangnya trombosit, berkurangnya sel darah putih, lemah, lelah, sesak nafas, mudah mengalami perdarahan, mudah terinfeksi, kulit membiru/menghitam, kering, gatal pada mulut, gatal pada tenggorokan, sariawan, sulit menelan, mual muntah, nyeri perut dan penurunan nafsu seks. Hal tersebut dapat mengakibatkan terjadinya gangguan dalam pemenuhan kebutuhan Activity Daily Living's. Penelitian ini juga sejalan dengan penelitian Fangel et.al (2013) bahwa wanita yang mengalami kanker payudara memiliki keterbatasan untuk melakukan perawatan diri sehari-hari seperti pekerjaan rumah tangga, perawatan diri dan kegiatan lainnya yang 
berdampak terhadap penurunan kualitas hidup.

Penelitian ini sejalan dengan pernyataan Nasir dan Munith (2010) bahwa salah satu intervensi yang dapat diberikan oleh petugas kesehatan untuk meningkatkan pelaksanaan Activity Daily Living's pasien kanker yaitu dengan memberikan program latihan Activity Daily Living Training yang diyakini mampu meningkatkan kemandirian pasien untuk menjalankan fungsi kehidupannya seperti perawatan diri sehari-harinya.

Pasein kanker yang menjalani perawatan harus aktif melakukan latihan pergerakan untuk menajga dan dapat menjalankan kemampuan perawatan diri sehari-hariseusai dengan kemampuan tubuh terhadap aktifitas fisik tersebut. Latihan pergerakan harus dilakukan sesuai dengan anjuran petugas kesehatan dan terprogram selama masa pengobatan atau perawatan. Periksakan kondisi kesehatan anda sebelum melakukan latihan pergerakan serta dapat mengkonsulta sikan kepada ahli terapi fisik untuk membantu latihan pergerakan yang aman, efektif dan menyenangkan bagi anda (American Cancer Society, 2014).

Keterbatasan peneltian ini adalah memiliki jumlah menggunakan tekkhnik nonprobability sampling, pelaksanaan intervensi yang dipantau oleh keluarga dan pemantaua kemampuan Activity Daily Living's memlalui laporan atau evaluasi $\log$ book yang dibagikan sebelumnya oleh peneliti tanpa di observasi langsung di rumah oleh, karena itu, diharapkan kepada peneliti selanjuntya untuk menggunakan penelitian yang sama, namun diharapkan dapat melakukan pemantauan dan membrikan langsung intervensi di rumah respobden selama program penelitian.

\section{KESIMPULAN}

Bedasarkan hasil penelitian tentang Activity Daily Living's Training terhadap kemampuan melakukan Activity Daily Living's yang meliputi: aktivitas pemenuhan nutrisi dan cairan, mobilisasi/pergerakan, aktivitas rumah, toileting, bathing, kebersihan diri dan pengobatan dapat ditarik kesimpulan terdapat pengaruh sebelum dan sesudah diberikan intervensi selama satu bulan dengan durasi waktu pelaksanaan intervensi 30 menit setiap latihan.

\section{DAFTAR PUSTAKA}

American Cancer Society. (2014). Physical activity and the cancer patient. https://www.cancer.org/treatment/surviv orship-during-and aftertreatment/ staying-active/physical-activity-and-thecancer-patient.html. Diakses pada tanggal 15 Agustus 2018.

American Occupational Therapy. (2011). Occupational Therapy and Breast CancerSurvivorship.https://www.aota.or $\mathrm{g} / /$ media/Corporate/Files/AboutOT/cons umers/Health-and-

Wellness/Breast\%20Cancer\%20tip\%20s heet.pdf. Diakses pada tanggal 09 Juni 2018.

Bakhtiar. 2012. Manfaat \&efek samping kemoterapi. http:// Manfaat dan efeksampingkemoterapi_Bakhtiar.htm diaksestanggal 27 Juni 2018.

Fangel, L.M.V., Panobianco, L.M.K., Almeida, A.M. \& Gozzo, T.O. (2013). Qualify of life and daily activities performance after breast cancer treatment. Journal Acta Paul.Enferm. ISSN:1982-0194.

Fain, J.A. (2009). Reading, understandingand apliying nursing research. $3^{\text {th }}$ Edition. Phidelphia: F.A Davis Company.

International Agency for Reseacrh on Cancer. (2013). Latest world cancer statistics global cancer burden rises to 14.1 million new cases in 2012: marked increase in breast cancers must be addressed.https://www.iarc.fr/en/med iacentre/pr/2013/pdfs/pr223_E.pdf .Diakses pada tanggal 15 Agustus 2018.

Lubis, N. \& Hasnida, 2009.Terapi perilaku kognitif pada pasien kanker, Medan: USU Press.

Moorhead, S., Jhonson, M., Maas, M.L., \& Swanson, E. (2013).Nursing outcomes clasiffication (NOC). Mosby:Elsevier.

Muhith,A., Nasir,A. (2011). Dasar-dasar keperawatan jiwa. Salemba Medika : Jakarta.

Polit, D. F.\& Beck, C.T. (2012). Nursing research: generation and assesing 
evidance for nursing practice. $9^{\text {th }}$ Edition. Philadelphia: Lippincott Williams \& Wilkins.

Taylor, S.G.\& Renpenning, K. (2011). Selfcare science, nursing theory and evidance based practice theory. New York: Springer Publishing Company.

Wood, J.L.\& Heber, J. (2014). Nursing research methods and critical appraisal for evidance-based-practice. $8^{\text {th }}$ Edition. St.Louis: Mosby Elsevier.

Zhao, C., [et.al]. (2013). Physical activity, psychological distress, and receipt of mental healthcare services among cancer survivors. $J$ Cancer Sarviv (2013) 7, 131-139. DOI:10.1007?s11764-012054-6.

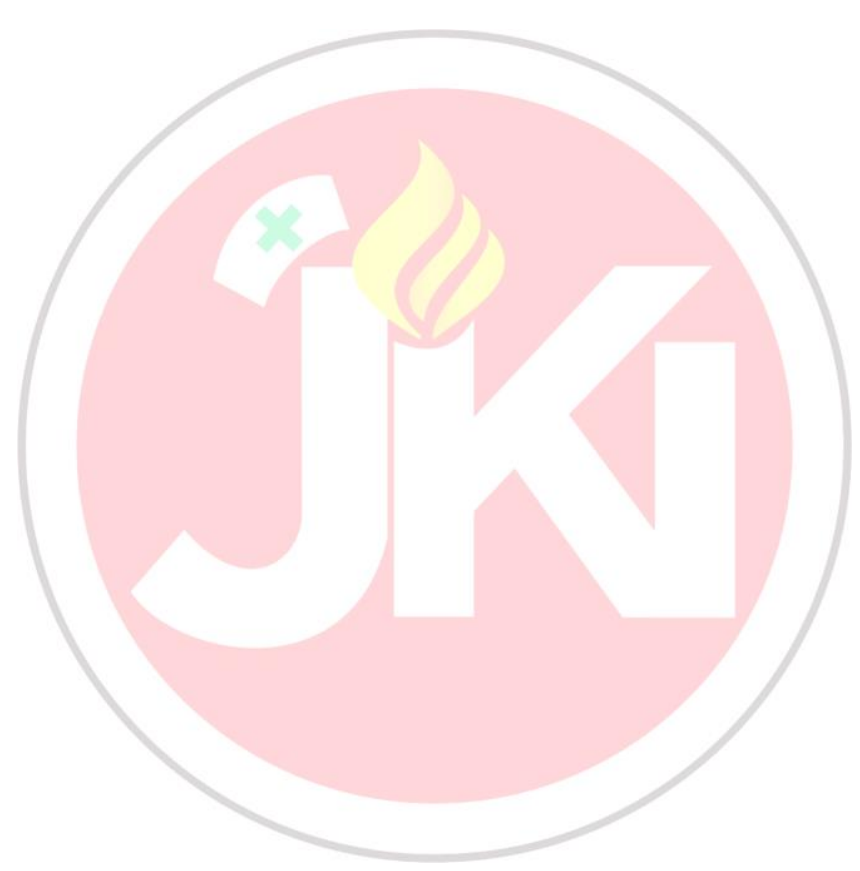

